\title{
Race, genetic determinism and the media: An exploratory study of media coverage of genetics and Indigenous Australians
}

\author{
EMMA KOWAL AND GERALD FREDERIC ${ }^{1}$
}

\begin{abstract}
Social scientists and Indigenous people have voiced concerns that media messages about genetics and race may increase the public's belief in genetic determinism and even increase levels of racism. The degree of genetic determinism in media messages has been examined as a determining factor. This study is the first to consider the implications of this area of scholarship for the indigenous minority in Australia. A search of the last two decades of major Australian newspapers was undertaken for articles that discussed Indigenous Australians and genetics. The review found 212 articles, of which 58 concerned traits or conditions that were presented in a genetically deterministic or antideterministic fashion. These 58 articles were analysed by topic, slant, and time period. Overall, 23 articles were anti-deterministic, 18 were deterministic, 14 presented both sides and three were ambiguous. There was a spike in anti-deterministic articles in the years after the Human Genome Diversity Project, and a parallel increase in deterministic articles since the completion of the Human Genome Project in 2000. Potential implications of the nature of media coverage of genetics for Indigenous Australians is discussed. Further research is required to test directly the impact of these messages on Australians.
\end{abstract}

\section{Introduction}

"New Zealand Maori carry a 'warrior' gene which makes them more prone to violence, criminal acts and risky behaviour, a scientist has controversially claimed." So began an Australian Associated Press article ${ }^{2}$ that rapidly spread throughout the English-speaking media in August 2006. It reported research findings presented by a genetic researcher that Maori were twice as likely as non-Maori to carry a gene associated with alcohol and tobacco use. ${ }^{3}$ The particular polymorphism of the gene that encodes the enzyme monoamine oxidase (MOA) has also been associated with risk-taking and aggression, and is consequently known as the 'warrior gene'. The international media were quick to take up the story that Maori were genetically predetermined to be violent, a depiction that the researchers argued was misrepresentation of their research. ${ }^{5}$ In the wake of the warrior gene controversy, Maori academics have argued that linking the MOA allele with high levels of violence among Maori is scientifically unsound, effectively makes being Maori a 'disease', and may lead to genetic and racial discrimination by insurance companies. Further, "contributions to racial stereotyping by trained scientists are unethical and scandalous". 6 Chant argued that media coverage of the 'warrior gene' story fed into and strengthened the dominant media discourse of Maori as uncivilised and dangerous to the general populace. ${ }^{7}$ By offering a biological explanation for Maori racial stereotypes, coverage of the warrior gene "reinforces already problematic stereotypes creating fear in an already fearful and distrustful public". 8

Indigenous ${ }^{9}$ peoples in New Zealand, Australia and elsewhere have expressed concerns about their involvement in genetic research. ${ }^{10}$ As one Maori scholar stresses, "Māori are acutely aware of the potential for genetic information to be used to discriminate, stigmatise and 'blame the victim'." "11 Further, Hudson and colleagues argue that "[m]edia 
representations of 'Māori' genes can interpret differences such as disparities in health as biologically ordained," thus undermining explanations for inequality based on the social determinants of health. ${ }^{12}$

More broadly, social scientists have argued that race-based messages about genetics could increase beliefs that racialised populations are both inherently different and inferior from dominant (usually white) populations. ${ }^{13}$ After an apparent decline in beliefs in biological differences between races in the second half of the 20th century, scholars have expressed concerns that a 're-biologisation of race' accompanying the genetic biotechnology revolution may see an increase in racist attitudes. ${ }^{14}$ This 're-biologisation' is nurtured by a media that gives disproportionate attention to stories that confirm genetic differences between racialised groups. ${ }^{15}$

Media reporting on ethnic minorities reflects and reinforces the dominant ideologies of a given society, and reporting on Indigenous peoples provides many pertinent examples. ${ }^{16}$ The long history of discrimination against Indigenous Australians provides plenty of fuel for media reporting that reinforces stereotypes of inferiority, violence, laziness, or disease ${ }^{17}$ Research has found widespread stereotyping and misrepresentation of Indigenous Australians in the media. ${ }^{18}$ Concurrent with this, racial prejudice towards Indigenous Australians continues to persist as a social concern. ${ }^{19}$ And while there is no existing evidence directly linking media reporting on Indigenous Australians and racial attitudes, research in other countries has found links between reporting and racist attitudes, as we explore in this article.

Indigenous scholars such as those cited above have powerfully argued that media reporting of genetics can reinforce racist attitudes in the general population, particularly the 'victim-blaming' beliefs that poor Indigenous health is the result of genetic inferiority rather than societal oppression. Responding to these concerns, we take the following question as a point of departure: Is it likely that coverage of Indigenous genetics in the Australian media could be increasing racist attitudes? This article will address this question from two angles. First, we review the existing international evidence concerning genetic determinism, racist attitudes and the media. Second, this article presents the first media analysis of genetics in relation to Aboriginal and Torres Strait Islander Australians. Articles from major Australian newspapers discussing Indigenous Australians and genetics from 1986-2009 were reviewed and analysed by topic, slant (from antideterministic to deterministic) and time period. Finally, in the light of this exploratory analysis, we discuss what effects, if any, media reports of Indigenous genetics may have on racist attitudes in the general population.

\section{Genetic determinism, essentialism and the media}

Throughout the 1990s and 2000s, media coverage of stories on genetics increased in parallel with rapid advances in the genetic sciences. As one of the major sources disseminating knowledge on contemporary science, the media plays an important role in shaping the beliefs of the public. In response to increasing media coverage of genetics, social scientists have examined the accuracy and possible effects of this coverage. ${ }^{20}$ The media has been identified by some critics as a major culprit in the rise of 'genetic essentialism', defined by Nelkin and Lindee as the effect of genetic discourse in "reduc[ing] the self to a molecular entity, equating human beings, in all their social, 
historical, and moral complexity, to their genes". ${ }^{21}$ One aspect of genetic essentialism is genetic determinism, whereby human traits, abilities and conditions are perceived as being determined by genetic factors (and by implication, not greatly determined by environmental factors). Such critics argue that the way the media reports on genetic research is likely to increase belief in genetic determinism, including the belief that racial differences are genetic, and that this will ultimately result in increased levels of both genetic discrimination and racism. ${ }^{22}$

Studies that have attempted to gain a deeper understanding of the relationship between media reporting of information about genetics and the public reception of that information have, however, painted a complex picture. An early study of news coverage of genetics from 1919 to 1995 found that two-thirds of articles attributed causality to genes and other factors, and that while only one-third attributed them to genes alone, there were almost no articles that denied any role for genes. ${ }^{23}$ More recent research by Bubela and Caulfield found that while there was a tendency for over-emphasis and exaggeration of certain topics - in particular the topic of behavioural genetics - the theory of 'geno-hype' appeared to be itself exaggerated by media critics. ${ }^{24}$ While their study identified a tendency to under-report risks and overemphasise benefits, they found that the 'hype' aspect of stories was generally located in the headline, with the body of articles often providing a more balanced picture. An analysis of US media articles on issues of genetics, race and human variation conducted by Lynch and Condit also found that both genetic and social theories of race were presented in most articles (even if one side was presented only in order to argue against it). This indicates that lay people are probably exposed to both sides of the controversy regarding the role of genetics in determining racial differences. ${ }^{25}$

There is also evidence to suggest that the public does not necessarily interpret general genetic discourse in the media as reinforcing the genetic determinist point of view. A 1999 study conducted by Condit has shown that the genetic 'blueprint' metaphor of DNA thought by certain critics to be an example of discourse that encourages belief in genetic determinism and discriminatory attitudes among the public - is not necessarily interpreted deterministically, with many college students interpreting it in non-deterministic and antideterministic ways. ${ }^{26}$ A blueprint can be "probabilistic rather than absolute, partial rather than totalistic, and [...] malleable rather than fixed" (p.172). Her study also found that a more progressive message that drew attention to the probabilistic nature of genotypes led to more explicitly anti-discriminatory views, suggesting that anti-deterministic articles may have the effect of reducing discriminatory attitudes.

\section{Genetic determinism and racism}

Nonetheless, concerns remain that the recent proliferation of media stories on genetics, and in particular those that present deterministic messages, may have an adverse impact, reinforcing racial prejudice. This concern is supported by several studies that have found significant correlations between the belief in genetic determinism (of human traits and behaviour) and levels of prejudice, including racism. ${ }^{27}$ Dambrun et al found group prejudice, including racism, to be mediated by belief in genetic determinism, to the effect that the more people believed in the power of environmental determinants of behaviour and personality, the lower the level of racism. Similarly, in Jayaratne et al.'s study into genetic lay theories among White Americans, a belief in genetic determinism of racial differences was found to be associated with greater prejudice toward Black Americans.

(C) ESRC Genomics Network. 
The study also reported that genetic lay theories of genetic determinism and antideterminism were employed to support prejudicial or tolerant views respectively.

Empirical studies have also found that racism based on ideas about genetics can be triggered by general messages about genetics. A study by Lynch et al examining the effects of media messages on racism has shown that media messages about genetics have a significant impact on racist attitudes. ${ }^{28}$ The authors showed that multiple exposures to very general genetic discourse (including, for example, messages about genetically modified foods, and the Human Genome Project) produced an increase in levels of genetically based racism. The messages used in the experimental study were, on average, moderately deterministic. Overall levels of racism and belief in genetic determinism were not, however, significantly increased. This suggests that those who already hold racist views are more likely to shift the basis of their views to genetic differences as a result of media messages about genetics, even when such messages are very general and only moderately deterministic.

More concerning is evidence reported by Keller in a study that analysed the belief in genetic determinism in relation to stereotyping, prejudice and other mechanisms of motivated social cognition. ${ }^{29}$ Beyond finding that belief in genetic determinism was significantly correlated with prejudice, including negative racial stereotyping, the study also found that rendering genetically essentialist information salient (i.e. 'priming') clearly increased levels of prejudice and in-group bias, particularly in persons holding preexisting essentialist beliefs. Respondents (German university students) in the test group were exposed to information that included the common genetic heritage of Europeans and scientific findings of differences in the frequencies of specific genes in different populations, but also the fact that greater genetic variation exists within, as opposed to between, populations (the latter is usually associated with anti-deterministic views). The results suggest that genetic messages that essentialise group differences, even when they do not draw connections with human traits and behaviours, can have a causal role in increasing levels of racial prejudice.

\section{Effects of media coverage of racialised genetics}

Given the empirical evidence concerning the links between exposure to genetic discourse and levels of racial prejudice, one would expect even more pronounced effects when genetic discourse in the media is not only deterministic, but discussed in connection with traits or behaviours of racialised populations. ${ }^{30}$ Researchers have in fact measured significant increases in overall levels of general racism in response to exposure to racialised genetic discourse. ${ }^{31}$ Of the few studies that have examined the impact of racialised messages about genetics on lay audiences, Condit et al's pioneering study found that race-specific messages about genetics and health increased overall levels of racism, genetically based racism, and one dimension of genetic discrimination. The message used in the study mentioned both genetically deterministic and non-deterministic arguments, stating that alongside the role of environmental factors such as exercise, smoking, and nutrition in heart disease, "[y]our family history matters too, because genetics also plays a role. Research studies indicate there are some medical treatments that work better for black men and women" (p. 404). ${ }^{32}$ Elsewhere, Condit and Bates offer a path model to explain these effects of genetic messages on various forms of racism. ${ }^{33}$ They argue that messages linking genetics, race, and health increase genetically based racism by

(C) ESRC Genomics Network. 
increasing general levels of racism. This is achieved by "increasing perceived group difference and perceived hierarchicalism of differences" (p. 102).

In summary, media stories about genetics - including those about racialised populations have been found to vary in their level of determinism, and often present both sides of the 'nature-nurture' argument. In addition, genetic concepts, such as the 'blueprint' metaphor, appear to be interpreted by lay audiences in a range of both deterministic and antideterministic ways. ${ }^{34}$ However, this mixed picture is problematised somewhat by experimental studies that show that belief in genetic determinism is associated with higher levels of racial prejudice, and that even moderately deterministic messages can trigger increases in genetically based racism. Further, messages that simply essentialise group differences can increase genetically based racism as well as overall levels of racism. How can these findings be drawn on to investigate the potential outcomes of media coverage of genetics and Indigenous Australians? Assuming that such experimental studies have some bearing on experiential reality, a logical first step is to assess the distribution of deterministic articles in the Australian media in order to gauge whether there is any cause for concern. As there have yet to be any Australian studies conducted on the subject, we draw on existing international literature to analyse the Australian print media coverage of genetics in relation to Indigenous Australians, and to consider what effect this coverage may have on the attitude of the Australian public towards Aboriginal and Torres Strait Islander people, who make up 2.5 per cent of the population. ${ }^{35}$

\section{Methodology}

A comprehensive literature search using the Lexis-Nexis database was performed to obtain media articles from all major national and state Australian newspapers from 1986 (the earliest year available in the database) to September 2009. The search looked for articles that had both (i) words related to Indigenous Australians ('Aboriginal' or 'indigenous' and 'Australia', or 'Torres Strait Islander') and (ii) words related to genetics (genetics', 'DNA', or 'genomics'). Articles were included only if they discussed genetics, DNA, or genomics in relation to Indigenous Australians and/or Torres Strait Islanders as a group. Articles were excluded if they referred only to indigenous people of countries other than Australia, if Indigenous people and genetics were not mentioned in relation to each other, or if they mentioned an Indigenous Australian as an individual who, for example, has a genetic disease, without stating or implying that Indigenous people as a group were susceptible to the disease.

Approximately 1,200 articles were screened, of which 212 articles fit the inclusion criteria. The latter were mostly news articles with a minority of feature articles and a few letters to the editor. Articles were coded for topic with a sample of 15 per cent of the articles also coded by the first author to ensure reliability. The articles selected discuss a diverse number of issues related to the genetics, DNA, and genomics of Indigenous Australians and Torres Strait Islanders. In descending order of frequency, the topics were: ancestry (including identity, human remains, ancestry testing and the assimilation era) (48\%), population genetics (including the Human Genome Diversity Project and Genographic Project) (14\%), disease (including diabetes and renal disease) (13\%), ethics of genetics (including privacy and ownership of genetic material) (12\%), sporting ability (7\%), addiction (including alcoholism and gambling) (5\%), forensics (4\%), sexual abuse $(1 \%)$, education, and suicide $(<1 \%)$.

(C) ESRC Genomics Network. 
These topics were then divided into two broad groups: those that did not discuss a human trait, and those that did. The first group included: ancestry, population genetics, ethics of genetics, and forensics. This accounted for 154 or 73 per cent of the articles. The second group of 58 articles pertained to features or properties of humans that can be discussed as more or less genetically determined. This group included: disease, addiction, sporting ability, sexual abuse, education, and suicide. The analysis and discussion presented in this paper refer to the 58 articles pertaining to human traits, as it is this set of articles that may vary in their degree of determinism.

Each article in this second group was analysed in two additional ways: slant and time period. First, the articles were coded for deterministic slant, i.e. for its degree of either 'genetic determinism' (meaning the article argued or implied that these traits were genetically determined), or 'anti-genetic determinism' (meaning the article presented the argument that these traits were not genetically determined). Following the scheme used by Lynch and $\mathrm{Condit}^{36}$ to determine deterministic slant of media articles, six categories were initially used in coding of slant. 'Yes/all' and 'No/all' coded for articles where the only position mentioned was that the condition or trait in question was genetically determined or that is was not genetically determined. 'Yes/mostly' and 'No/mostly' coded for articles where there was a clear slant towards determinism or anti-determinism respectively, but where the opposite argument was mentioned also. 'Both sides' coded for articles where genetic determinism and anti-determinism were given approximately equal support. 'Ambiguous' articles were those with no evident implication of determinism or antideterminism (reflecting that the mention of Indigenous people and genetics in the article was brief).

As a way of assessing change across time, we grouped the articles into three time periods (1986-1993, 1994-2001, 2002-September 2009) to see whether the ratio of deterministic to anti-deterministic articles had changed or remained constant. These time periods were chosen to be equal in length, but they also broadly capture the effects of two important events in the history of genetic research. The second time period (1994-2001) is influenced by the Human Genome Diversity Project which generated considerable bad press in Australia in the mid-1990s, as it did worldwide, ${ }^{37}$ while the third time period (2002-2009) captures any changes in the aftermath of the completion of the Human Genome Project in 2000. In addition, while analysing the articles, three major discursive trends were noted and are discussed below.

\section{Results}

The topics covered are shown in Table 1 (below). The main topics discussed in these 58 articles were: disease (48\%), addiction (19\%) and sporting ability (26\%). 
Table 1: Topics of Articles Pertaining to Human Traits*

\begin{tabular}{lc}
\hline \multicolumn{1}{c}{ Topic of Article } & $\begin{array}{c}\text { No. of Articles Mentioning } \\
\text { Topic }\end{array}$ \\
& \\
\hline Disease & $\mathbf{2 8}$ \\
- Diabetes & 15 \\
- Renal disease & 4 \\
- Heart disease & 2 \\
- Low birth weight & 2 \\
- Machado Joseph & 1 \\
- Meningococcal disease & 1 \\
- HIV & 1 \\
- Other & 6 \\
Sporting ability & $\mathbf{1 5}$ \\
Addiction & $\mathbf{1 1}$ \\
- Alcoholism & 11 \\
- Gambling & 1 \\
Sexual abuse & $\mathbf{2}$ \\
Education & $\mathbf{1}$ \\
Suicide & $\mathbf{1}$ \\
Total & $\mathbf{5 8}$ \\
\hline
\end{tabular}

* Note some articles mentioned more than one topic.

\section{Slant}

Three of the articles had an ambiguous slant (two of these concerned addiction and one concerned sport). Among the remaining 55 articles, there was a diversity of slant presented, although anti-deterministic articles were somewhat better represented (See Table 2). Eighteen were deterministic in slant (the sum of Yes/all and Yes/mostly), 23 antideterministic (the sum of No/all and No/mostly), and 14 articles implied a balance of support for both sides. Note that there were no articles where the question of whether a trait was genetically determined was itself the main focus of the story. Despite this, in all of the articles discussing a human trait, excepting the three coded as ambiguous, the issue of determinism was discussed sufficiently to judge the slant present.

(C) ESRC Genomics Network. 
Table 2: Deterministic Slant of Articles

\begin{tabular}{|c|c|c|}
\hline Deterministic Slant & Number of Articles & E.g. \\
\hline Yes/all ${ }^{\mathrm{a}}$ & 14 & $\begin{array}{l}\text { "The genetics passed on from their gifted } \\
\text { spear-fishing ancestors make them superior } \\
\text { target-finders" (Pandaram 2008) }\end{array}$ \\
\hline Yes/mostly ${ }^{\mathrm{b}}$ & 4 & $\begin{array}{l}\text { "While genetic programming is just one part of } \\
\text { the jigsaw surrounding alcoholism, he believes } \\
\text { it will prove significant" (O'Leary 1990) }\end{array}$ \\
\hline Both sides $^{c}$ & 14 & $\begin{array}{l}\text { "A combination of racial genetic predisposition } \\
\text { and dietary problems appears to cause these } \\
\text { high rates [of renal disease]" (Gray 2000) }\end{array}$ \\
\hline Ambiguous ${ }^{\mathrm{d}}$ & 3 & - \\
\hline No/mostly ${ }^{\mathrm{e}}$ & 2 & $\begin{array}{l}\text { "Social factors rather than genetics are blamed } \\
\text { for the huge gaps in health and life } \\
\text { expectancy...there are obviously some genetic } \\
\text { and biological issues" (Cronin 2008) }\end{array}$ \\
\hline No/all ${ }^{f}$ & 21 & $\begin{array}{l}\text { "There is absolutely no evidence that } \\
\text { Aborigines have a genetic or racial } \\
\text { predisposition to alcohol consumption" (Zwar } \\
\text { 1992) }\end{array}$ \\
\hline
\end{tabular}

Notes:

a The only position mentioned in the article is that the trait/condition is genetically determined.

b The majority of the article supports genetic determinism, but the anti-genetic position is mentioned.

c Both genetic determinism and anti-determinism are given approximately equal support within the article.

d No slant is evident.

e The majority of the article supports genetic anti-determinism, but the deterministic position is mentioned.

$\mathrm{f}$ The only position mentioned in the article is that the trait/condition is not genetically determined.

The degree of determinism and anti-determinism varied across topics. In terms of the main topics covered, articles on disease tended to be more deterministic (11 deterministic, 7 anti-deterministic, and 10 both sides), articles on addiction more anti-deterministic (3 deterministic, 6 anti-deterministic, 0 both sides), and articles on sporting ability more antideterministic (4 deterministic, 6 anti-deterministic, 4 both sides).

\section{Change in slant over time}

In general, reporting on Indigenous Australians regarding purported links between genetics and human traits showed a trend of increasing from 1986 to September 2009 (see Table 3). Two main findings stand out from the analysis of slant across time. First, there is

(C) ESRC Genomics Network. 
an increase in anti-deterministic articles in the period 1994-2001 (from 3 to 12), largely reflecting articles relating to sporting ability, and a decrease in the number of deterministic articles (from 4 to 2). This finding may reflect an anti-deterministic backlash following the Human Diversity Genome Project in the 1990s. Second, there is an increase in deterministic articles in the period 2002-Sept 2009. This increase largely consists of articles about sporting ability and disease. This finding may reflect a response to the completion of the sequencing of the human genome in the 2000s and the expansion in genetic research in its aftermath.

Table 3: Slant Across Time*

\begin{tabular}{lcccc}
\hline & $1986-1993$ & $1994-2001$ & 2002-Sept 2009 & TOTAL \\
\hline Deterministic & $\mathbf{4}(44 \%)$ & $\mathbf{2}(11 \%)$ & $\mathbf{1 2}(43 \%)$ & $\mathbf{1 8}(33 \%)$ \\
Both sides & $\mathbf{2 ( 2 2 \% )}$ & $\mathbf{4}(22 \%)$ & $\mathbf{8}(29 \%)$ & $\mathbf{1 4}(25 \%)$ \\
$\begin{array}{l}\text { Anti- } \\
\text { deterministic }\end{array}$ & $\mathbf{3 ( 3 3 \% )}$ & $\mathbf{1 2}(67 \%)$ & $\mathbf{8}(29 \%)$ & $\mathbf{2 3}(42 \%)$ \\
\multicolumn{1}{c}{ TOTAL: } & $\mathbf{9}$ & $\mathbf{1 8}$ & $\mathbf{2 8}$ & $\mathbf{5 5}$ \\
\hline
\end{tabular}

Note:

* Articles with an ambiguous slant are excluded from this table (2 articles in period 1994-2001, 1 article in period 2002-Sept 2009). Some percentages do not add up to $100 \%$ due to rounding.

\section{Discursive Frames}

In addition to assessing whether a particular article was deterministic or anti-deterministic, we also noted that there were three different discourses within which determinism or antideterminism were discussed. ${ }^{38}$ Approximately 75 per cent of all articles were framed within a discourse of 'susceptibility', as they presented information pertaining to the genetic susceptibility of Indigenous Australians to physical and mental health problems, especially diabetes and alcoholism. Within this susceptibility frame, deterministic articles were often matter-of-fact, and commonly drew on scientific authority without emotive language or social comment. In contrast, the anti-deterministic articles within this discourse were often passionate and presented as challenging scientific authority, arguing that Indigenous health problems are socially and not genetically determined.

The other 25 per cent of articles were framed within a discourse of 'positive' determinism, meaning here that a trait generally seen as positive was mentioned in relation to genetic or environmental/social determinants. With the exception of one article that discussed Indigenous Australians in the context of a possible genetic resistance to disease (in this

(C) ESRC Genomics Network. 
case, HIV), all of these articles discussed genetic factors in relation to the supposedly exceptional sporting abilities of Indigenous Australians in 'Australian rules' football, running, rugby, cricket, and hockey. Within this discourse, anti-deterministic articles were again more passionate, arguing against stereotyping of Indigenous people and the reduction of individual success in sport to genetic factors.

The third trend that was identified was a subset of anti-deterministic articles that employed parody as a discursive tool. Parody was used to ridicule attitudes of White Australians that linked alcoholism, violence, or poor performance in the education system to genes rather than socioeconomic circumstances. It was also used to argue that stereotypes of Indigenous athletes were nonsensical racial clichés, and that certain differential laws for Indigenous people and assumptions about them were racist.

\section{Discussion}

There are few published studies with which this analysis of media coverage can be directly compared. It is also difficult to draw conclusions about the extent to which coverage corresponds to the current views of the scientific community as there is no consensus among scientists on the level of genetic determinism of human traits. ${ }^{39}$ Although articles reviewed in this study were, overall, more anti-deterministic than deterministic ( $42 \%$ vs $33 \%$ ), there was a significant proportion that presented both sides fairly equally $(25 \%)$, indicating that media reporting was reasonably balanced overall. Lynch and Condit's review of newspaper articles about genetics and race in the US found that media coverage presented a range of views on the question of whether race was genetic or socially constructed. ${ }^{40}$ Although the authors did not specifically examine the level of genetic determinism with regards to traits and conditions such as diseases, this study confirms their finding that media reporting on genetics and race is fairly balanced, largely presenting both sides of the argument to the public.

While balanced reporting should be comforting, in light of findings that race-specific messages about genetics and health that are wholly or partially deterministic increase both racist attitudes generally and genetically based racism in particular, this comfort may well be unfounded. ${ }^{41}$ On the basis of such studies, evidence would suggest that 58 per cent of the articles (deterministic and partially deterministic ['both sides'] articles) may lead to an increase in overall levels of racism and levels of genetically-based racism in the public.

It is not clear from existing literature whether the discourse we identified as 'positive' determinism (where genetics is associated with positive traits like sporting ability), which represented 26 per cent of the articles, would have a different impact on audiences than the discourse of 'susceptibility'. If the impact of race-based genetic messages derives from a reinforcement of essentialist views of race, then one would not expect the 'positive' determinism to differ in their impact from the remainder of the articles, as 'positive' determinism is no more or less essentialist than a belief that disease or addiction is genetically determined. This is supported by US research on 'complementary' stereotypes, such as the belief that African-Americans have more athletic and musical ability than whites, which indicates that endorsement of such stereotypes is associated with prejudiced attitudes and beliefs (for example, beliefs that African-Americans are inferior to whites). ${ }^{42}$ Research into complementary stereotypes about Indigenous people in an Australian context is warranted. 
The significant proportion of anti-deterministic articles in our study may be cause for some comfort if it is true that anti-deterministic messages result in decreased levels of prejudice in the public. This is suggested by findings that belief in environmental determinants of behaviour and personality are correlated with lower levels of racial prejudice, ${ }^{43}$ and that (non-race-based) messages presenting a less deterministic picture of genotypes has the potential to lead to more anti-discriminatory attitudes. ${ }^{44}$ Existing research, however, cannot tell us whether an anti-deterministic message in the context of debates about genetics and race would produce a decrease in overall levels of racism. It may be the case that anti-deterministic articles could still have a negative impact on public attitudes by the mere fact of discussing race in relation to genetics, a proposition that is partly supported by Keller's study ${ }^{45}$. There is a need for further research into the impact of anti-deterministic messages to address the question of whether anti-deterministic messages about genetics and race decrease, increase or do not affect levels of racism and genetically based racism in the general public.

Whatever the impact of anti-determinist messages, this may become less important if the increase in deterministic messages and decrease in proportion of anti-deterministic articles in the 2000 s continues into this decade. If this increase reflects the rapid advancements in genetic science over the last decade, one could expect this trend to continue, particularly given the likelihood of more genetic research in Indigenous populations in the near future as genetic diversity is targeted as a source of scientific discovery. ${ }^{46}$

Clearer evidence on the impact of deterministic and anti-deterministic messages is also crucial for developing policies in this area. One important policy option to consider is media guidelines for the reporting of Indigenous genetics. One potential model to follow is the range of reporting guidelines provided by Australian Press Council, that aim to ensure that media reporting is fair and accurate. Some of these guidelines explicitly aim to reduce negative bias against a specific group. For example, guidelines on the reporting of asylum seekers advises against the terms 'illegal boatpeople' or 'illegals' used by some media outlets to describe people arriving by boat to request asylum in Australia. ${ }^{47}$ The Australian Broadcasting Commission has issued guidelines specific to reporting Indigenous issues, arguing that "publishers and broadcasters should not distribute material that is likely to incite or perpetuate hatred against, severely ridicule or incite serious contempt for, a person or group based on the reason that the person is an Aboriginal or Torres Strait Islander or the group is composed of Aboriginal or Torres Strait Islanders." ${ }^{48}$ Given these existing guidelines, the question of whether guidelines for reporting of Indigenous genetics may be warranted should be explored, particularly as stories of this kind are likely to increase in number in the coming years.

The findings and discussion presented in this article should be seen in the context of the broader, ongoing debate about how scientists conceive of genetic differences between populations and the implications of their research. ${ }^{49}$ Media guidelines have the potential to address the way genetic research findings are reported, but larger questions concern the ways that scientists conceive of racial differences and construct scientific studies accordingly, especially studies involving Indigenous minorities. 
This article has examined the reporting of genetics and Indigenous Australians over more than two decades in the Australian media. Interpreting the findings of the analysis presented is constrained by the mixed evidence generated from international research and the limitations of this exploratory study. Absolute numbers were small and articles were distributed across different Australian regions, so conclusions about their impact must be made with some caution. In addition, the study does not compare coverage of Indigenous genetics with any other Indigenous issue, nor any other ethnic group. The study was also confined to the print media. It is possible that television, radio and on-line media may differ in the kinds of issues about Indigenous genetics that they cover, and in the frequency of coverage.

Further research could examine the effects of both anti-deterministic and deterministic media stories about Indigenous people and genetics on a representative sample of nonindigenous Australians. As discussed, understanding the effects of a range of messages on individuals with a range of pre-existing views about racial minorities could inform any proposed media guidelines, particularly with regards to whether anti-deterministic messages are desirable, or whether they differ little in their impact from deterministic messages. Given the likely increase in genetic research in Indigenous Australian populations in coming years, such research would generate an evidence base to drive ethical scientific communication practices and help protect Aboriginal and Torres Strait Islander communities from potential harms of genetic research.

\section{Acknowledgements}

Thanks to Lobna Rouhani for research assistance. Research for this paper was supported by an Australian National Health and Medical Research Council Aboriginal and Torres Strait Islander Training Fellowship (\#454813) and a University of Melbourne Early Career Research Grant.

\footnotetext{
${ }^{1}$ School of Social and Political Sciences, University of Melbourne. Correspondence to: e.kowal@unimelb.edu.au

${ }^{2}$ Australian Associated Press, 2006. 'Warrior gene' blamed for Maori violence [online]. http://news.ninemsn.com.au/national/120718/warrior-gene-blamed-for-maori-violence [Accessed 29 December 2010].

${ }^{3}$ R. Lea and G. Chambers. Monoamine Oxidase, Addiction, and the "Warrior" Gene Hypothesis. The New Zealand Medical Journal 2007; 120 (1250): 1-6.

${ }^{4}$ J. Stoke. 2006. Family Tragedy Behind Gene Work. New Zealand Herald.

${ }^{5}$ Lea and Chambers, op.cit. note 3

${ }^{6}$ R. Hook. "Warrior Genes" and the Disease of Being Maori. MAI Review 2009; 2: p.6.

${ }^{7}$ L. Chant. Discourses on Indigenity: The Media, the Warrior Gene and Aggressive Caucasians. MAI Review 2009; 2: 1-4.

${ }^{8}$ P. Harris. Responsible research and the media trap. MAI Review 2009; $2: 2$.

${ }^{9}$ In this article, 'indigenous' is capitalised when referring to Indigenous Australians, and not capitalised when referring to indigenous people in general. Indigenous Australians and Aboriginal and Torres Strait Islanders are used interchangeably in this article to refer to people who are descended from the pre-colonial population of Australia.

${ }^{10}$ For example, M. Dodson. Human Genetics: Control of research and sharing of benefits. Australian Aboriginal Studies 2000; 1 \& 2: 56-64; Indigenous Peoples Council on Biocolonialism, 2000. Indigenous Peoples, Genes and Genetics: What Indigenous Peoples Should Know About Biocolonialism [online]. http://www.ipcb.org/publications/primers/index.html [Accessed 29 December 2010]; K.Tallbear. 2007.
} 
Narratives of Race and Indigeneity in the Genographic Project. Journal of Law, Medicine and Ethics 2007; 35 (3): 412-24; Y. Paradies, M.J. Montoya, and S.M. Fullerton. Racialized Genetics and the Study of Complex Diseases: The Thrifty Genotype Revisited. Perspectives in Biology and Medicine, 2007; 50 (2): 203-227.

${ }^{11}$ M. Hudson et al. Whakapapa - A Foundation for Genetic Research?. Journal of Bioethical Inquiry 2007;

4 (1): 43-49.

12 Ibid, p. 47.

${ }^{13}$ M. Wetherell and J. Potter. 1992. Mapping the language of racism: discourse and the legitimation of exploitation. New York: Harvester Wheatsheaf.

${ }^{14}$ C. Condit et al. Exploration of the Impact of Messages About Genes and Race on Lay Attitudes. Clinical Genetics 2004; 66: 402-408; T. Duster. Race and Reification in Science. Science 2005; 307 (5712): 1050-1; T. Caulfied et al. Race and Ancestry in Biomedical Research: Exploring the Challenges Genome Medicine 2009; 1 (8): 81-88.

${ }^{15} \mathrm{P}$. Sankar. Hasty generalisation and exaggerated certainties: reporting genetic findings in health disparities research. New Genetics and Society 2006; 25 (3): 249-264.

${ }^{16}$ M.A. Weston. 1996. Native Americans in the News: Images of Indians in the Twentieth Century Press. Westport: Greenwood Press; R.M. Entman and A. Rojecki. 2000. The black image in the white mind: Media and race in America. Chicago: University of Chicago Press.

${ }^{17}$ H. Reynolds. 1987. Frontier: Aborigines, Settlers and Land. St Leonards: Allen and Unwin; J. Chesterman and B. Galligan. 1997. Citizens Without Rights: Aborigines and Australian Citizenship. Cambridge: Cambridge University Press.

${ }^{18}$ M.A. Brough. A Lost Cause? Representations of Aboriginal and Torres Strait Islander Health in Australian Newspapers. Australian Journal of Communication 1999; 26 (2): 89-98; M. Meadows. 2001. Voices in the Wilderness: images of Aboriginal people in the Australian media. Westport: Greenwood Press. ${ }^{19}$ D. Mellor. Contemporary Racism in Australia: The Experiences of Aborigines. Personality and Social Psychology Bulletin 2003; 29 (4): 474-486; N. Priest et al. Racism as a determinant of social and emotional wellbeing for Aboriginal Australian youth. Medical Journal of Australia 2011; 194 (10): 546-550.

${ }^{20}$ See, for example: C. Condit, N. Ofulue and K. Sheedy. Determinism and Mass-Media Portrayals of Genetics. American Journal of Human Genetics 1998; 62: 979-984; G. Geller, B. Bernhardt and N. Holtzman. The Media and Public Reaction to Genetic Research. JAMA, 2001; 287 (6): 773; G. Geller et al. Houseofficers' Reactions to Media Coverage About the Sequencing of the Human Genome. Social Science and Medicine, 2003; 56: 2211-2220; P. O'Mahoney and M. Schafer. The 'Book of Life' in the Press: Comparing German and Irish Media Disocurse on Human Genome Research. Social Studies of Science 2005; 35 (1): 99-130.

${ }^{21}$ D. Nelkin and M.S. Lindee. 2004. The DNA Mystique: The Gene as a Cultural Icon. Ann Arbor: University of Michigan Press.

${ }^{22}$ R.A. Hubbard and E. Wald. 1993. Exploding the gene myth: how genetic information is produced and manipulated by scientists, physicians, employers, insurance companies, educators and law enforcers.

Boston: Beacon Press; A. Lippman. 1998. The politics of health: Geneticization versus health promotion. In: S. Sherwin (ed.) The politics of women's health. Philadelphia: Temple University Press; B.K. Rothman. 1998. Genetic Maps and Human Imaginations: The Limits of Science in Understanding Who We Are. New York: W.W. Norton \& Co; V.T. Silva. In the beginning was the gene: The hegemony of genetic thinking in contemporary culture. Communication Theory 2005; 15: 100-123.

${ }^{23}$ Condit et al, op. cit., note 20.

${ }^{24}$ T. Bubela and T. Caulfield. Do the Print Media "Hype" Genetic Research? A Comparison of Newspaper Stories and Peer-Reviewed Research Papers. Canadian Medical Association Journal 2004; 170 (9): 13991407.

${ }^{25}$ J. Lynch and C. Condit. Genes and Race in the News: A Test of Competing Theories of News Coverage. American Journal of Health Behaviour 2006; 30 (2): 125-135.

${ }^{26}$ C. Condit. How the Public Understands Genetics: Non-deterministic and Non-Discriminatory Interpretations of the "Blueprint" Metaphor. Public Understanding of Science 1999; 8: 169-180.

${ }^{27}$ T. Jayaratne et al. White Americans' Genetic Lay Theories of Race Differences and Sexual Orientation: Their Relationship with Prejudice toward Blacks, and Gay Men and Lesbians. Group Processes and Intergroup Relations 2006; 9 (1): 77-94; M. Dambrun et al. Why Does Social Dominance Orientation Decrease With University Exposure to the Social Sciences? The Impact of Institutional Socialization and the Mediaitng Role of "Geneticism". European Journal of Social Psychology 2009; 39: 88-100. 
${ }^{28}$ J. Lynch et al. A Preliminary Study of How Multiple Exposures to Messages About Genetics Impact on Lay Attitudes Towards Racial and Genetic Discrimination. New Genetics and Society 2008 ; 27 (1): $43-56$.

${ }^{29}$ J. Keller. In Genes We Trust: The Biological Component of Psychological Essentialism and Its Relationship to Mechanisms of Motivated Social Cognition. Journal of Personality and Social Psychology 2005; 88 (4): 686-702.

30 'Racialised' refers to the process of recognising a particular group as ethnically or racially different from the dominant group in a given society.

${ }^{31}$ Condit et al, 2004, op. cit. note 14 .

${ }^{32}$ Ibid.

${ }^{33}$ C. Condit and B. Bates. How lay people respond to messages about genetics, health, and race. Clinical Genetics 2005; 68 (2): 97-105.

${ }^{34}$ See C. Condit. "When Do People Deploy Genetic Determinism? A Review Pointing to the Need for Multi-factorial Theories of Public Utilization of Scientific Discourses." Sociology Compass 2011; 5 (7): 618-635.

${ }^{35}$ Australian Bureau of Statistics and Australian Institute of Health and Welfare, 2010. The Health and Welfare of Australia's Aboriginal and Torres Strait Islander Peoples. 2010. Canberra: Australian Bureau of Statistics.

${ }^{36}$ Lynch and Condit, op.cit. note 25

${ }^{37}$ Anonymous. 1994. Vampire tests anger Aborigines. The Advertiser. Adelaide; J. Reardon. 2005. Race to the Finish: Identity and Governance in an Age of Genomics. Princeton, N.J., Princeton University Press.

${ }^{38}$ The analysis of discourses relating to genetically determined traits has been the subject of a great deal of scholarship. A selection of relevant texts includes Condit, op. cit. note 26; Nelkin and Lindee, op. cit. note 21; P. Atkinson, P. Glasner et al, (eds.). 2007. New Genetics, New Identities. New York Routledge; B.

Koenig and S.-J. Lee (eds.). 2007. Revisiting Race in a Genomic Age. Newark, Rutgers University Press; I. Whitmarsh and D.S. Jones (eds.). 2010. What's the Use of Race? Modern Governance and the Biology of Difference. Cambridge, MA, MIT Press; A. Plows. 2011. Debating Human Genetics: Contemporary Issues in Public Policy and Ethics. New York, Routledge.

${ }^{39}$ See C. Condit. Public Understandings of Genetics and Health. Clinical Genetics 2010; 77: 1-9; Condit 2011 op.cit. note 34.

${ }^{40}$ Lynch and Condit, op. cit. Note 25.

${ }^{41}$ Condit et al, op.cit. note 14; Condit and Bates op.cit. note 32; Dambrun et al, op. cit. note 27.

42 A. Czopp and M. Monteith. Thinking Well of African Americans: Measuring Complimentary Stereotypes and Negative Prejudice. Basic and Applied Social Psychology 2006; 28 (3): 233-50.

${ }^{43}$ Dambrun et al op. cit. Note 27.

${ }^{44}$ Condit. op. cit. note 26.

${ }^{45}$ Keller, op.cit. note 29.

${ }^{46}$ C.D. Bustamante, E.G. Burchard et al. Genomics for the World. Nature 2011; 475: 163-165. This is not to deny the perpetually delayed emergence of promised practical benefits of the genomic revolution. Fortun is one of a number of authors who characterise genomics as a 'promissory science'. M. Fortun. 2008.

Promising Genomics: Iceland and deCODE Genetics in a World of Speculation. Berkeley: University of California Press.

${ }^{47}$ Australian Press Council, 2010. Guidelines on Press Reporting [online].

http://www.presscouncil.org.au/pcsite/activities/gprguide.html [Accessed 29 December 2010].

${ }^{48}$ Australian Broadcasting Corporation, 2010. Cultural Protocols for Indigenous Reporting in the Media [online]. Sydney, p.32. http://www.sydneyr.det.nsw.edu.au/support/abedequity/abed/culturalprotocol.pdf [Accessed 29 December 2010].

${ }^{49}$ D. Fullwiley. The Molecularization of Race: Institutionalizing Human Difference in Pharmacogenetics Practice. Science as Culture 2007; 16 (1): 1-30; D. Fullwiley. The Biologistical Construction of Race: 'Admixture' Technology and the New Genetic Medicine. Social Studies of Science 2008; 38 (5): 695-735; A. Smart, R. Tutton, P. Martin, G. Ellison and R. Ashcroft. The Standardization of Race and Ethnicity in Biomedical Science Editorials and UK Biobanks. Social Studies of Science 2008; 38 (3): 407-423; M.J. Montoya. 2011. Making the Mexican Diabetic: Race, Science, and the Genetics of Inequality. Berkeley: University of California Press. 